An investigation of authentic leadership's individual and group influences on follower responses

By: Carol Gill and Arran Caza

Gill, C., \& Caza, A. (2018). An investigation of authentic leadership's individual and group influences on follower responses. Journal of Management, 44(2), 530-554.

https://doi.org/10.1177/0149206314566461

***(C) 2015 The Authors. Reprinted with permission. No further reproduction is authorized without written permission from SAGE. This version of the document is not the version of record. Reuse is restricted to non-commercial and no derivative uses. ***

\begin{abstract}
:
In this study, we investigated and clarified aspects of the multilevel nature of authentic leadership (AL) and its effects on followers. Specifically, we hypothesized that AL would have distinct effects through both personalized AL, which is a leader's direct effect on a follower, and through generalized AL, which is a leader's indirect or group-based effect on a follower as a result of leadership effects among the follower's coworkers. These hypotheses were consistent with a complete review of the empirical literature on AL's effects and the results from a sample of leaders and followers working in a large multinational company. The data showed that the two paths of AL's influence had distinct relationships with follower responses. We discuss the implications of these results, particularly those concerning how to study the multilevel effects of AL.
\end{abstract}

Keywords: authentic leadership | multilevel analysis | identification | social influence | trustworthiness | trust | psychological capital | leader-member exchange

\title{
Article:
}

Authentic leadership (AL) has emerged as an important and popular construct in the last decade, largely in response to numerous high-profile scandals (Caza \& Jackson, 2011). Both popular media (e.g., George \& Sims, 2007) and academic research (Gardner, Cogliser, Davis, \& Dickens, 2011) have devoted great attention to the topic. In the literature, AL is defined as a set of interrelated behaviors concerning how leaders act toward followers, make ethical decisions, and use information (Avolio, Gardner, Walumbwa, Luthans, \& May, 2004; Gardner et al., 2011). A recent review paper by Gardner and colleagues (2011) summarized the findings of empirical studies linking AL to follower responses, and subsequent work has linked authentic leadership to even more follower outcomes (e.g., Caza, Bagozzi, Woolley, Levy, \& Caza, 2010; Hsiung, 2012). However, significant gaps remain in the literature (Gardner et al., 2011). In particular, research has neglected important levels-of-analysis issues (Gardner et al., 2011; Yammarino, Dionne, Schriesheim, \& Dansereau, 2008).

AL theory is maturing, moving beyond demonstrating the value of the construct to elaborating and clarifying its associated processes, and doing so requires clearer conceptualization and 
empirical rigor, particularly across levels of analysis (Cho \& Dansereau, 2010; Gardner et al., 2011; Yammarino et al., 2008). While it has been acknowledged that AL is a multilevel phenomenon, construct definitions and analysis do not clearly address levels-of-analysis issues (Yammarino et al., 2008). Without clear theory and empirics, inappropriate techniques may mislead conclusions and derail the field's development (X. Wang \& Howell, 2012).

Our study addresses these issues by theoretically explaining and empirically examining both individual and group-based effects from AL. Numerous studies have examined AL at the individual level (Gardner et al., 2011), and more recently, some studies have examined AL at the group level (e.g., Clapp-Smith, Vogelgesang, \& Avey, 2009; Hsiung, 2012). However, we are not aware of any study that has considered group-based and individual AL influences simultaneously. Moreover, as we explain below, there are both theoretical and methodological questions raised by the previous group-level analyses of AL, and we suggest an alternative that addresses these questions and provides a clear path for future theory development.

Specifically, we adopted a new approach by distinguishing between the influences of personalized AL ( $\left.\mathrm{P} \_\mathrm{AL}\right)$, which concerns a leader's direct effect on a follower, and generalized AL (G_AL), which concerns a leader's indirect effect on a follower as a result of the leader's direct effects among the follower's coworker group. We found that $\mathrm{P}_{-}$AL had positive effects on the most important follower outcomes associated with AL and that G_AL also had a positive relationship with two of these four outcomes. As such, our article advances AL theory by clearly specifying the mechanisms underlying group-based effects and providing evidence consistent with those mechanisms. The results indicate how future theorizing and investigation can take account of the multiple ways in which AL influences followers. In addition, our article updates Gardner and colleagues' (2011) review in an effort to contribute to the integrated and empirically informed development of AL theory.

\section{Theoretical Foundations}

AL has been defined in different ways, and disagreement remains (see review by Gardner et al., 2011), but we adopt the definition that has informed most empirical studies conducted. Specifically, authentic leaders are those who exhibit behaviors in four dimensions (Gardner et al., 2011; Walumbwa, Avolio, Gardner, Wernsing, \& Peterson, 2008). Self-awareness is the first dimension and refers to leaders' understanding of their strengths and weaknesses and their impact on others. Transparency is the second dimension and concerns leaders openly sharing information and expressing their genuine selves to others. The third dimension is balanced processing, which refers to leaders objectively analyzing all relevant data before making a decision. The fourth dimension, internalized moral perspective, refers to leaders being guided by internal morals and aligning their behavior with these values. These four dimensions of behavior have been found to be mutually reinforcing, with optimum explanatory power obtained when they are treated as a set rather than individually (Walumbwa et al., 2008). As such, to the extent that followers perceive leaders to engage in these behaviors, the literature defines those leaders as authentic (e.g., Cianci, Hannah, Roberts, \& Tsakumis, in press; Leroy, Anseel, Gardner, \& Sels, 2015). 
Defined in this way, AL has been linked empirically with more than 30 follower responses. However, theory prioritizes four of these responses as the most proximal and important. These four central follower responses - identification with the leader, belief in the trustworthiness of the leader, positive states, and positive social exchanges - have been proposed to mediate and explain the other effects of AL on followers (Avolio et al., 2004; Avolio \& Gardner, 2005; Ilies, Morgeson, \& Nahrgang, 2005). The central importance of these four outcomes has also received some empirical support (e.g., Walumbwa, Wang, Wang, Schaubroeck, \& Avolio, 2010; H. Wang, Sui, Luthans, Wang, \& Wu, 2014). As a result, these four responses are presumed to be the most important consequences of $\mathrm{AL}$, and they are the focus of our investigation.

Our aim in this article is to consolidate, clarify, and extend AL theory. Toward that end, we take three steps. First, we report the results of a thorough review of the empirical literature. We add 46 studies to the seven in Gardner and colleagues' (2011) review, and for each article, we distinguish the level of analysis at which AL was operationalized. Second, we consider the rationale and evidence for the existence of distinct group-based and individual effects of AL on followers, explaining why one should expect both $\mathrm{P} \_\mathrm{AL}$ and G_AL to influence outcomes. Finally, we report on new empirical data that provide the first simultaneous test of $\mathrm{P} \_\mathrm{AL}$ and G_AL effects on the four central responses. Figure 1 summarizes the effects of AL on follower responses.

Group level

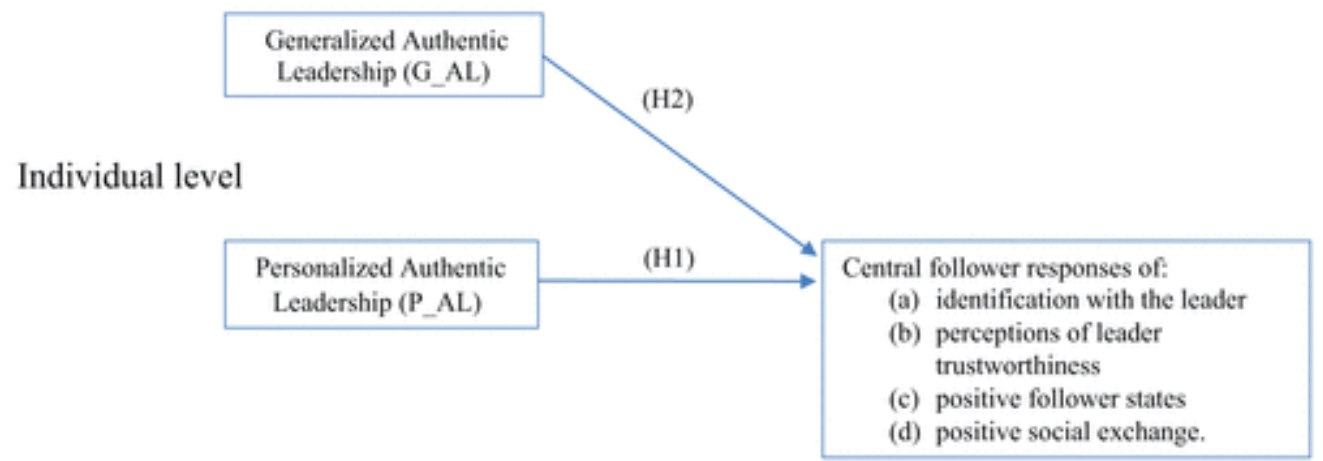

Figure 1. A Model of the Effects of Authentic Leadership on Central Follower Responses

\section{Review of Empirical Studies}

We conducted a comprehensive literature search to identify empirical studies linking AL to follower responses. In April 2014, we conducted forward citation searches in Google Scholar on the two established AL measures: the Authentic Leadership Questionnaire (ALQ; Walumbwa et al., 2008) and the Authentic Leadership Inventory (ALI; Neider \& Schriesheim, 2011). We chose Google Scholar for its comprehensiveness. Our search identified 423 citations to the ALQ and 25 to the ALI from 2010 onward (i.e., since the Gardner et al., 2011, review). We examined these citations and retained articles that were peer reviewed, available in English, and reported on the relationship between follower-rated $\mathrm{AL}$ and some outcome variable. We did not include findings concerning the antecedents of AL (e.g., Randolph-Seng \& Gardner, 2012) or leader self-reports of AL (e.g., Cerne, Dimovski, Maric, Penger, \& Skerlavaj, in press). 
Gardner and colleagues' (2011) review identified seven relevant empirical studies, and our search found an additional 46. Table 1 presents a summary of the 53 studies that have linked AL to follower outcomes. Consistent with our interest in investigating the direct personalized and indirect group-based ways in which AL influences followers, Table 1 also distinguishes the level of measurement at which AL was operationalized (i.e., individual or group average scores). The table is organized using AL theory's existing classification scheme (Avolio et al., 2004; Avolio \& Gardner, 2005; Ilies et al., 2005), which distinguishes among three types of outcome: central follower responses, follower attitudes, and follower behaviors. Table 1 thus presents a summary of all of the empirical evidence concerning the effect of AL on followers, organized by level of analysis and type of effect.

Table 1. Empirical Evidence on the Relationships Between Authentic Leadership (AL) and Follower Responses

\begin{tabular}{|c|c|c|}
\hline Follower Response & Individual AL Score & Group Average AL Score \\
\hline \multicolumn{3}{|l|}{ Central follower responses } \\
\hline Identification & $\begin{array}{l}\text { Walumbwa, Wang, Wang, Schaubroeck, \& Avolio, } 2010 \\
\text { (personal identification) } \\
\text { Wong, Spence Laschinger, \& Cummings, } 2010 \text { (personal } \\
\text { identification and social identification) }\end{array}$ & \\
\hline $\begin{array}{l}\text { Assessment of leader } \\
\text { trustworthiness and/or } \\
\text { trust in leader }\end{array}$ & $\begin{array}{l}\text { Erkutlu \& Chafra, } 2013 \\
\text { Wong \& Cummings, } 2009 \\
\text { Wong \& Giallonardo, } 2013 \\
\text { Wong et al., } 2010\end{array}$ & $\begin{array}{l}\text { Clapp-Smith, Vogelgesang, } \\
\text { \& Avey, 2009 } \\
\text { Leroy, Palanski, \& Simons, } \\
2012\end{array}$ \\
\hline Positive states & $\begin{array}{l}\text { Avey, } 2014 \text { (PsyCap) } \\
\text { Hannah, Avolio, \& Walumbwa, } 2011 \text { (moral courage) } \\
\text { Hystad, Bartone, \& Eid, } 2014 \text { (PsyCap) } \\
\text { Peterson, Walumbwa, Avolio, \& Hannah, } 2012 \text { (PsyCap) } \\
\text { Rego, Sousa, Marques, \& Pina e Cunha, } 2012 \text { (PsyCap) } \\
\text { Rego, Sousa, Marques, \& Pina e Cunha, } 2014 \text { (Positive Affect) } \\
\text { Woolley, Caza, \& Levy, } 2011 \text { (PsyCap) }\end{array}$ & $\begin{array}{l}\text { Hsiung, } 2012 \text { (positive mood) } \\
\text { Özkan \& Ceylan, } 2012 \\
\text { (collective efficacy) } \\
\text { Rego, Vitória, Magalhães, } \\
\text { Ribeiro, \& Pina e Cunha, } \\
2013 \text { (team virtuousness) }\end{array}$ \\
\hline Positive social exchanges & H. Wang, Sui, Luthans, Wang, \& Wu, 2014 & Hsiung, 2012 \\
\hline \multicolumn{3}{|l|}{ Follower attitudes } \\
\hline Satisfaction with leader & $\begin{array}{l}\text { Peus, Wesche, Streicher, Braun, \& Frey, } 2012 \\
\text { Walumbwa, Avolio, Gardner, Wernsing, \& Peterson, } 2008\end{array}$ & \\
\hline Job satisfaction & $\begin{array}{l}\text { Azanza, Moriano, \& Melero, } 2013 \\
\text { Giallonardo, Wong, \& Iwasiw, } 2010 \\
\text { Jensen \& Luthans, } 2006 \\
\text { Spence Laschinger, } 2012 \\
\text { Spence Laschinger \& Fida, in press-a } \\
\text { Spence Laschinger, Wong, \& Grau, } 2012 \\
\text { Walumbwa et al., 2008 } \\
\text { Wong \& Spence Laschinger, } 2013\end{array}$ & \\
\hline Career satisfaction & Spence Laschinger, 2012 & \\
\hline Well-being & & Özkan \& Ceylan, 2012 \\
\hline Organizational commitmer & $\begin{array}{l}\text { Darvish \& Rezaei, } 2011 \\
\text { Guerrero, Lapalme, \& Seguin, in press } \\
\text { Peus et al., } 2012 \\
\text { Spence Laschinger et al., } 2012 \\
\text { Walumbwa et al., } 2008\end{array}$ & $\begin{array}{l}\text { Leroy et al., } 2012 \\
\text { Özkan \& Ceylan, } 2012 \\
\text { Rego et al., } 2013\end{array}$ \\
\hline
\end{tabular}




\begin{tabular}{|c|c|c|}
\hline Follower Response & Individual AL Score & Group Average AL Score \\
\hline Intentions to turnover & $\begin{array}{l}\text { Jensen \& Luthans, } 2006 \\
\text { Spence Laschinger, } 2012 \\
\text { Spence Laschinger \& Fida, in press-b } \\
\text { Spence Laschinger et al., } 2013\end{array}$ & \\
\hline Engagement/burnout ${ }^{\mathrm{a}}$ & $\begin{array}{l}\text { Bamford, Wong, \& Spence Laschinger, } 2013 \\
\text { Giallonardo et al., } 2010 \\
\text { Spence Laschinger \& Fida, in press-a, in press-b } \\
\text { Spence Laschinger et al., } 2012 \\
\text { Walumbwa et al., } 2010 \\
\text { Wong \& Cummings, } 2009 \\
\text { Wong et al., } 2010 \\
\text { Alok \& Israel, } 2012\end{array}$ & \\
\hline $\begin{array}{l}\text { Promotive organizational } \\
\text { focus }\end{array}$ & Alok, 2014 & \\
\hline Empowerment & $\begin{array}{l}\text { Shapira-Lishchinsky \& Tsemach, in press } \\
\text { Walumbwa et al., } 2010 \\
\text { Wong \& Spence Laschinger, } 2013\end{array}$ & \\
\hline $\begin{array}{l}\text { Basic need satisfaction } \\
\text { (autonomy, competence, } \\
\text { relatedness) }\end{array}$ & & $\begin{array}{l}\text { Leroy, Anseel, Gardner, \& } \\
\text { Sels, } 2015\end{array}$ \\
\hline Justice perceptions & & Li, Yu, Yang, Qi, \& Fu, 2012 \\
\hline Inclusion & Cottrill, Lopez, \& Hoffman, 2014 & \\
\hline $\begin{array}{l}\text { Perceptions of support from } \\
\text { group }\end{array}$ & Wong \& Cummings, 2009 & \\
\hline Loyalty to leader & Monzani, Ripoll, \& Peiro, 2014 & \\
\hline Perceptions of climate & $\begin{array}{l}\text { Borgersen, Hystad, Larson, \& Eid, in press } \\
\text { Guerrero et al., in press } \\
\text { Hystad et al., } 2014 \\
\text { M. Nielsen, Eid, Mearns, \& Larsson, } 2013 \\
\text { Woolley et al., } 2011\end{array}$ & $\begin{array}{l}\text { Hsiung, } 2012 \\
\text { Ozkan \& Ceylan, } 2012\end{array}$ \\
\hline \multicolumn{3}{|l|}{ Follower behaviors } \\
\hline Collaboration & Spence Laschinger \& Smith, 2013 & \\
\hline $\begin{array}{l}\text { Ethical and prosocial } \\
\text { behavior }\end{array}$ & $\begin{array}{l}\text { Cianci, Hannah, Roberts, \& Tsakumis, in press } \\
\text { Hannah et al., } 2011\end{array}$ & \\
\hline Antisocial behavior & $\begin{array}{l}\text { Erkutlu \& Chafra, } 2013 \\
\text { Spence Laschinger et al., } 2012 \\
\text { Spence Laschinger \& Fida, in press-b } \\
\text { M. Nielsen, } 2013 \\
\text { Read \& Spence Laschinger, } 2013\end{array}$ & \\
\hline Support for leader & Willams, Pillai, Deptula, \& Lowe 2012 & \\
\hline Voice & $\begin{array}{l}\text { Wong et al., } 2010 \\
\text { Yagil \& Medler-Liraz, } 2014\end{array}$ & Hsiung, 2012 \\
\hline Feedback seeking & Qian, Lin, \& Chen, 2012 & \\
\hline Extra effort & Peus et al., 2012 & \\
\hline $\begin{array}{l}\text { Organization citizenship } \\
\text { behavior }\end{array}$ & $\begin{array}{l}\text { Cottrill et al., } 2014 \\
\text { Shapira-Lishchinsky \& Tsemach, in press } \\
\text { Song \& Seomun, } 2014 \\
\text { Walumbwa et al., } 2008 \\
\text { Walumbwa et al., } 2010\end{array}$ & Li et al., 2012 \\
\hline Absenteeism & Shapira-Lishchinsky \& Tsemach, in press & \\
\hline Ingratiation & Yagil \& Medler-Liraz, 2014 & \\
\hline Unbiased self-presentation & Yagil \& Medler-Liraz, 2014 & \\
\hline
\end{tabular}




\begin{tabular}{|llc|}
\hline Follower Response & Individual AL Score & Group Average AL Score \\
\hline Individual creativity & Muceldili, Turan, \& Erdil, 2013 & Li et al., 2012 \\
& Rego et al., 2012 & \\
Performance & Hystad et al., 2014 (accident rates) & Leroy et al., 2015 (role \\
& Wong \& Giallonardo, 2013 (adverse patient outcomes) & performance) \\
& Peterson et al., 2012 (job performance) & Li et al., 2012 (role \\
& H. Wang et al., 2014 (job performance) & performance) \\
& Walumbwa et al., 2008 (job performance) & Ozkan \& Ceylan, 2012 \\
& Wong \& Cummings, 2009 (job performance) & (reputation) \\
& Wong \& Spence Laschinger, 2013 (job performance) & Rego, Reis Junior, \& Pina e \\
& Peus et al., 2012 (perceptions of team effectiveness) & Cunha, in press (sales \\
& Wong et al., 2010 (quality of care) & achievement) \\
\hline
\end{tabular}

Note: PsyCap = psychological capital.

${ }^{a}$ Empirical evidence suggests that burnout and engagement are two ends of a single continuum (Cole, Walter, Bedeian, \& O'Boyle, 2011), so they are combined here.

\section{Distinct Personalized and Generalized Effects of AL}

Despite its having always been described as a multilevel phenomenon (Avolio \& Gardner, 2005; Yammarino et al., 2008), to our knowledge, no previous study has clearly specified or examined multiple effects from AL. Previous studies have examined only individual or groupbased effects in isolation (Gooty, Serban, Thomas, Gavin, \& Yammarino, 2012). In particular, Gardner et al.'s (2011) review and our expansion of it found that most studies examined the direct effect of a leader's AL on an individual follower, and the remaining studies examined the effects of AL using a group average score. Individual and group-based effects have not previously been considered together, which prevents the development of theory about their distinct effects.

Although ours is the first simultaneous study of multiple effects from AL, there is reason to expect distinct effects. In particular, prior work has linked follower responses to both individuallevel AL (e.g., X. Wang et al., 2012; Woolley, Caza, \& Levy, 2011) and group average AL (e.g., Clapp-Smith et al., 2009; Rego, Reis Júnior, \& Pina e Cunha, in press), suggesting that both levels can have an effect. Moreover, theory supports the expectation of distinct effects, as we explain below.

\section{P_AL and Follower Responses}

Leaders directly influence individual responses by interacting with followers (Wu, Tsui, \& Kinicki, 2010). A leader may produce differentiated responses as a result of genuine differences in how that leader behaves toward individual followers or through differences in how followers perceive the leader's behavior (Henderson, Liden, Glibkowski, \& Chaudhry, 2009; Wu et al., 2010). Either way, the possibility exists for a leader to have a unique, direct effect on a particular follower's outcomes. We refer to this aspect of leadership influence as $\mathrm{P}_{-} \mathrm{AL}$, and in this section, we describe how P_AL influences the four central outcomes of AL.

\section{$P \_$AL and leader identification}

Individuals' identities describe how persons think of themselves (Kreiner, Hollensbe, \& Sheep, 2006). Identification with a target is the feeling that one's relationship with that target is an 
important, self-defining aspect of one's identity (Sluss \& Ashforth, 2007). Identifying with a leader, therefore, involves a follower's belief that following that leader is an important part of who the follower is as a person.

Authentic leaders may induce followers' identification by transparently and consistently displaying their personal values, which allows followers to recognize that they share similar values with the leader or to decide that they want to emulate the leader's values (Avolio et al., 2004). As well, the values associated with AL are generally considered to be normative and appealing (Gardner, Avolio, Luthans, May, \& Walumbwa, 2005), and so their display can make the leader seem an inherently admirable person with whom a follower would want to identify (Luthans \& Avolio, 2003). In addition, the authentic leader's self-awareness, transparency, and internalized moral perspective make the leader an attractive role model who displays high ethical standards, honesty, and integrity (Avolio et al., 2004), all of which make the leader an attractive target for identification. Moreover, an authentic leader's transparency and balanced processing make him or her more likely to discuss his or her values with followers (Luthans \& Avolio, 2003) and to emphasize the growth and development of followers (Avolio \& Reichard, 2008; Leroy et al., 2015), further increasing opportunities for value similarity and subsequent identification. Consistent with these arguments, empirical research has linked P_AL with follower identification (Walumbwa et al., 2010; Wong, Spence Laschinger, \& Cummings, 2010).

\section{$P_{-} A L$ and trustworthiness}

Trust is defined as a willingness to be vulnerable to the actions of another, and an individual will trust another to the extent that he or she feels the other is trustworthy (Colquitt, Scott, \& LePine, 2007; Mayer, Davis, \& Schoorman, 1995). Followers judge leaders to be more trustworthy to the extent that they believe the leader can deliver something that followers value (competence), cares about followers' interests (benevolence), and displays consistency between espoused values and behavior (integrity; Mayer et al., 1995).

AL behaviors make leaders more likely to be positively evaluated in all three aspects of trustworthiness. Regarding competence, leaders with wisdom, good interpersonal skills, and jobrelevant knowledge are most likely to be judged as competent (Gabarro, 1978). Balanced processing and self-awareness will contribute to attributions of wisdom in an authentic leader (McKenna, Rooney, \& Boal, 2009). Both balanced processing and relational transparency facilitate open leader-follower communication and sharing of critical information and perceptions (Avolio et al., 2004), which will enhance authentic leaders' interpersonal skills and job-relevant knowledge. Similarly, followers should perceive authentic leaders as more benevolent (i.e., loyal, caring, and supportive; Mayer et al., 1995) because the leader considers followers' concerns and viewpoints (balanced processing) and is willing to share information and express his or her inner feelings and thoughts (transparency; Avolio et al., 2004). Finally, the authentic leader's consistent ethical and moral values will combine with transparency to produce follower perceptions of integrity (i.e., fairness, justice, consistency; Colquitt et al., 2007). Authentic leaders display honesty and ethical behavior, make fair decisions, and share the reasons behind the decisions they make (Avolio et al., 2004). AL should thus increase a leader's trustworthiness, and empirical evidence supports this expectation (Wong \& Cummings, 2009). 


\section{P_AL and positive states}

Theory has associated AL with several positive states in followers, most notably, psychological capital (PsyCap; durable psychological resources that enhance performance; Jensen \& Luthans, 2006) and positive affect (noncognitive responses to stimuli; Gooty, Gavin, \& Ashkanasy, 2009). Authentic leaders' seeking of input from followers (balanced processing) and their transparency in interpersonal relationships meet followers' psychological needs and foster positive responses, such as increased PsyCap and positive affect (Leroy et al., 2015; Peterson, Walumbwa, Avolio, $\&$ Hannah, 2012). Followers of authentic leaders are free to ask for advice, voice their concerns, and challenge the leader. As well, authentic leaders' self-awareness enables them to understand their impact on a follower and to adjust their behavior to respond to a follower's needs. Selfawareness and transparency also cause leaders to express their genuine emotions, providing emotional support to followers to do the same. AL can thus contribute to positive states among followers, as shown in several empirical studies (Avey, 2014; Hystad, Bartone, \& Eid, 2014; Peterson et al., 2012; Rego, Sousa, Marques, \& Pina e Cunha, 2012, 2014; Woolley et al., 2011).

\section{P_AL and positive social exchange}

Social exchange refers to a relationship based on long-term and unspecified mutual obligations, rather than self-serving contractual ones (Blau, 1964). Social exchange between a leader and follower involves reciprocal interactions and feelings based on trust, respect, and obligation and is referred to as leader-member exchange (LMX; Graen \& Uhl-bien, 1995). Authentic leaders' relational transparency, which includes openness and truthfulness in relationships, fosters positive social exchange (Ilies et al., 2005). Moreover, authentic leaders follow an internalized moral perspective, causing followers to view them as consistent and principled decision makers, which also fosters positive social exchange (Brown \& Trevino, 2006; Zhang, Wang, \& Shi, 2012). Balanced processing and the empathy that arises from self-awareness will lead followers to believe their leader is committed to them and thus deserving of reciprocal commitment (Erdogan, Linden, \& Kraimer, 2006; Wayne, Shore, Bommer, \& Tetrick, 2002). In addition, authentic leaders' balanced processing prompts them to seek input from followers, which will further contribute to positive social exchange by increasing the frequency with which the leader and follower interact (Dienesch \& Liden, 1986). In support of this reasoning, there is consistent evidence linking AL to positive social exchange in the form of enhanced LMX (Hsiung, 2012; Walumbwa et al., 2010; H. Wang et al., 2014; Wong et al., 2010).

On the basis of all of the above, we expected our data to replicate previous findings, showing that P_AL has a direct positive effect on the four central follower outcomes of AL.

Hypothesis 1: $\mathrm{P} \_\mathrm{AL}$ will have a positive relationship with the four central follower responses of (a) identification with the leader, (b) perceptions of leader trustworthiness, (c) positive follower states, and (d) positive social exchange.

G-AL and Follower Responses 
In addition to their direct effects on followers, authentic leaders will also have indirect, groupbased effects on followers, which we refer to as G_AL. Unfortunately, while there is empirical evidence linking group-level AL to follower outcomes, a complete theoretical explanation for those relationships has not been provided. Specifically, there have been eight studies conducted that examine AL at the group level. ${ }^{1}$ These studies are of two general types, and neither type offers a full theoretical explanation for the group-based effects of AL.

The first group comprises the majority of the studies (Hsiung, 2012; Leroy et al., 2015; Leroy, Palanski, \& Simons, 2012; Li, Yu, Yang, Qi, \& Fu, 2012; Özkan \& Ceylan, 2012). These studies use an aggregated, group-level AL construct for statistical or measurement reasons. The articles' theoretical explanations for how AL affects follower responses are given entirely at the individual level (i.e., leader behaviors directly influencing individual followers' reactions). Moreover, with only one exception (Leroy et al., 2015), group-level considerations are not even mentioned in these articles until the Methods section, at which time the authors explain that aggregation was used either to accommodate a hierarchically nested data structure or to correct for individual differences and get a reliable estimate of "uniformly displayed" AL. However, no explanation is given for why uniformly displayed AL is important, and in fact, a focus on it seems potentially inconsistent with the direct leader-follower mechanisms used to explain the effects of AL in these articles.

The second group (Clapp-Smith et al., 2009; Rego et al., 2014; Rego, Vitória, Magalhães, Ribeiro, \& Pina e Cunha, 2013) includes some theoretical rationale for the use of group-level AL. These articles refer to issues of shared perception and feeling, such as social contagion, mutual reinforcement, and converging mental models. The common feature in these explanations is that group-based effects result from follower interactions. For example, Follower A perceives the leader to have some degree of authenticity, that perception influences how Follower A acts, and the actions of Follower A are assumed to influence Follower B. The specific process and rationale for these influences are not fully explained, but the assumption seems to be that AL can have an indirect effect on a given follower, as a result of its direct effect on that follower's coworkers. In these articles, group-level AL is referred to as a collective phenomenon that "emerges" from follower interactions. Unfortunately, the nature of that phenomenon and the process of its emergence are not specified, nor do any of the theoretical mechanisms described specifically include the role of a collective phenomenon.

In all eight studies, the researchers adopted a direct consensus composition model (Chan, 1998), though none used that term, nor did they explain why that model was the most appropriate. This lack of explanation is problematic, because the choice of composition model is a fundamental one that influences the meaning of one's findings (Wallace et al., 2016). To use a direct consensus composition model, one assesses the level of agreement among individuals in a group, and if agreement is sufficient, that agreement is assumed to indicate the existence of a distinct group-level phenomenon. In contrast to previous research, we are skeptical about the appropriateness of the direct consensus model for studying AL. Our doubts arise from both empirical and theoretical concerns.

\footnotetext{
${ }^{1}$ The Gardner, Cogliser, Davis, and Dickens (2011) review included one additional (ninth) group-level study (Hoy $\&$ Henderson, 1983). However, that paper was based on a very different definition and operationalization of authentic leadership, such that it is not comparable to the studies addressed in this article. We exclude it here.
} 
Empirically, a direct consensus model relies upon agreement among followers. However, five of the eight group-level AL studies (Hsiung, 2012; Leroy et al., 2012, 2015; Li et al., 2012; Rego et al., 2013) reported relatively low intraclass correlation 2 (ICC[2]) values for AL. ICC(2) is an assessment of the reliability with which a variable can be used to distinguish among groups and is considered an important indicator of the statistical meaningfulness of a group-level construct (Van Mierlo, Vermunt, \& Rutte, 2009). The fact that the majority of previous studies had low between-group reliability suggests that there was little consistent variation from group to group, arguing against the influence of a shared, group-level phenomenon. As such, it is not clear that much statistical support has been found for the existence or importance of "aggregate" AL.

Moreover, numerical agreement is not sufficient to justify aggregation, nor is it the most important consideration. There must be a coherent theoretical explanation of the nature of the group-level phenomenon and how the individual-level responses constitute that phenomenon (Chan, 2011). Such an explanation has not been given. For example, even if one assumes that AL causes followers to become more similar in their perspective and to develop shared mental models (e.g., Rego et al., 2014), then it is those mental models that exist at the group level, not AL itself. The mental convergence account has no explanation of, or need for, a group-level AL construct. No previous research has offered a thorough explanation of the nature of a direct consensus-derived AL measure. Similarly, theoretical explanations of the effect of AL have also not made reference to the influence of an aggregate phenomenon.

In fact, contrary to the existence of a distinct, group-level AL phenomenon, the explanations that have been offered seem more consistent with an additive composition model. In an additive composition model, agreement among individuals is not required, as the group effect is assumed to result from the cumulative addition of each individual member's contribution (Chan, 1998). The additive composition model therefore does depend upon the emergence or ontological reality of a distinct group-level phenomenon; rather, it is based on interpersonal influences that result from group composition. Until such time as a coherent theoretical explanation is given for the nature and importance of "aggregate" or "uniformly displayed" AL, the additive composition model appears theoretically and statistically preferable as a way to think about group-based effects from AL.

Indeed, adopting an additive composition model to understand group-based AL effects offers several advantages. For one, doing so is more parsimonious. It does not require the existence of an (as yet undefined) construct of aggregate authentic leadership. Moreover, it allows AL theory to explain group-based effects by drawing on well-established theory and findings about how coworkers influence each other (we summarize these explanations below). In addition, adopting an additive composition model addresses the problem of low agreement among followers and offers other methodological advantages, as described in the Methods section later in this article. However, the most important benefit of using an additive composition model is consistency with existing AL theory. By assuming that group-based effects result from the accumulation of individual responses, one need not assume that a leader behaves similarly with every follower or that all followers have identical perceptions of their leader. Since AL theory assumes variety in leaders' dyadic interactions (Yammarino et al., 2008), it seems questionable to focus only on uniformly shared perceptions of AL. 
As such, we propose the adoption of an additive model, based on the assumption that the more AL behavior a leader displays with any given follower, the more that follower will display the associated behavioral and attitudinal changes and, as a result, interact differently with coworkers. We submit that the group-based effects associated with AL stem from changes in followerfollower interactions. The more AL any particular follower experiences, the more that follower's behavior toward peers changes, so that in groups where most members experience high levels of AL, work group interactions will be noticeably different from those in groups where most followers do not perceive their leader as authentic. G_AL therefore concerns the summed effect of $\mathrm{P}_{-}$AL experienced by group members, and G_AL thus influences an individual follower's responses through three interrelated processes: social identification (Hogg, 2001), social learning (Bandura, 1971), and social contagion (Meindl, 1995).

\section{G_AL and social identification}

Social identity theory explains how an individual's identity is affected not only by his or her personal attributes but also by his or her membership in groups (Tajfel, 1982). Social identification is defined as the degree to which an individual assigns emotional and value significance to his or her membership in a group (Hogg, 2001). As described previously, the followers of authentic leaders are more likely to identify with their leader, to consider their leader trustworthy, to experience positive states, to develop positive social exchange with their leader, and to subsequently have many other positive outcomes, such as increased performance and job satisfaction (e.g., Azanza, Moriano, \& Melero, 2013; Peus, Wesche, Streicher, Braun, \& Frey, 2012). Coworkers with such qualities are more attractive as peers (Staw, Sutton, \& Pelled, 1994) and thus more likely to induce social identification in colleagues (Hogg \& Turner, 1985). Therefore, the more one's coworkers experience AL, the more likely one is to value membership in their social group (i.e., to develop social identification). In other words, the more P_AL one's coworkers individually experience (i.e., the higher the level of G_AL), the more likely one will be to identify with that group of coworkers.

Individuals who identify with a group come to resemble its members (Abrams \& Hogg, 1990). When we identify with a group, our perceptions are biased to emphasize our similarity with the prototypical group member (Hogg \& van Knippenberg, 2003). In addition, given our desire to belong to the group, we are more likely to adopt the qualities we see in it (Hogg, 2001; Hogg \& Terry, 2000; Hogg \& van Knippenberg, 2003; Hogg, van Knippenberg, \& David, 2012). As a result, followers who identify with a group are likely to emulate their coworkers (van Knippenberg \& Wilke, 1992), including those coworkers' responses to their leader. For example, if our coworkers find the leader trustworthy or pursue positive relationships with the leader, we are more likely to do so as well, so as to be a "real" member of the group. Therefore, each coworker's experience of $\mathrm{P}_{-} \mathrm{AL}$ will influence his or her peers, such that the higher the level of G_AL, the more likely one is to display similar responses (i.e., outcomes associated with AL).

While there are no empirical studies directly linking G_AL to social identification, there are some findings consistent with the relationship. Wong and Cummings (2009) found that followers in groups with authentic leaders were more likely to perceive that they were in a supportive group. Likewise, Hsiung (2012) found that followers in groups led by authentic leaders reported 
a more positive group climate. As such, it seems likely that a part of the effect of G_AL on followers can be explained by changes in coworkers' responses that lead to increased social identification with those coworkers.

\section{G_AL and social learning}

The effect of AL on one's coworkers is also likely to influence individual outcomes through social learning. Social learning theory indicates that followers learn from observing others and that the group can influence individuals by preferentially reinforcing some behaviors (Bandura, 1971). In other words, one's coworkers provide important information about how to behave (Hogg, 2001).

With regard to AL, coworker responses to the leader (e.g., identification with leader and belief in leader trustworthiness) will influence the behaviors that a follower observes among peers. The more members of a group who have such feelings and display the associated behaviors, the stronger will be the group norm concerning those feelings and behaviors (Cialdini \& Goldstein, 2004; Turner, 1991). As a result, if most of a follower's coworkers experience high levels of P_AL, that follower is more likely to observe, and be reinforced for displaying, the outcomes

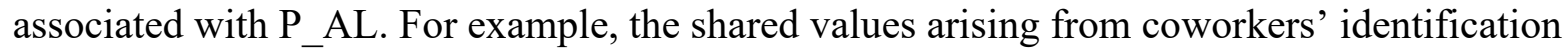
with the leader will make the group more likely to consistently reinforce certain values (e.g., openness, honesty, integrity). This reinforcement will influence a follower to adopt those values, and in doing so, the follower will become more similar to the leader and thus more likely to identify with the leader and to feel positively about the leader (Hogg \& van Knippenberg, 2003; Sherony \& Green, 2002; van Knippenberg, 2011). Social learning is thus another means by which G_AL may influence follower outcomes.

\section{G_AL and social contagion}

In addition to the processes of social identification and social learning, AL also may indirectly influence followers through social contagion, which explains the unintentional, nonconscious ways in which coworkers can influence each other (Meindl, 1990). In particular, as noted previously, $\mathrm{P} \_$AL is likely to produce positive affective reactions in followers, and these emotions can spread to other individuals through the process of emotional contagion (Hsee, Hatfield, Carlson, \& Chemtob, 1990). Emotional contagion has also been found to influence interactions and group processes, including cooperation and conflict (Barsade, 2002; Sy, Côté, \& Saavedra, 2005). As a result, social contagion within a group is likely to influence a follower's responses to reflect those of peers, providing an additional route by which G_AL may affect individual outcomes.

In summary, it should be noted that the three processes above- - social identification, social learning, and social contagion - are likely to be interdependent and mutually reinforcing in their effects (Hogg \& Terry, 2000). For example, the more identified one is with a group, the more powerful its social learning influences are likely to be; one's desire to be a member of the group will increase the influence of that group's reinforcements. As such, we propose that G_AL influences a follower's responses through social influence processes. That is, the group-based effect of AL arises from each follower personally experiencing some level of P_AL and 
exhibiting the associated responses. Those responses then socially influence the followers' coworkers, so that the effect of G_AL results from the sum consequence of coworkers' reactions to the leader. This leads to our second hypothesis.

Hypothesis 2: G_AL will have a positive relationship with the four central follower responses of (a) identification with the leader, (b) perceptions of leader trustworthiness, (c) positive follower states, and (d) positive social exchange.

\section{Methods}

Data

We collected data in one division of a large, multinational corporation. Fifty-two team leaders were identified by the human resources (HR) department, and all of those leaders' direct reports were sent links to confidential online surveys to be completed during work time. Followers from 34 groups responded, but we excluded the three groups that had less than $50 \%$ follower response rates. Our final sample consisted of 31 leaders ( $60 \%$ response rate) and 104 followers ( $81 \%$ response rate). The leader sample was $55 \%$ female, with a modal categorical age of 35 to 50 years. All but two of the leaders had at least a bachelor's degree, and they had an average of 18.2 years of work experience $(S D=7.5)$, with 12.3 of those in management $(S D=6.9)$. The follower sample was $49 \%$ female, with a modal categorical age of 35 to 50 years. Most of them (63\%) had bachelor's degrees and more than 10 years' work experience. Most had been working with their leader for 1 to 3 years.

To reduce common method bias in the data, followers completed two separate surveys, an average of 3 days apart. In Survey 1, followers rated their leader's behavior, using the 16-item ALQ (Walumbwa et al., 2008). In Survey 2, they completed measures of the four outcomes: identification with leader (Mael \& Ashforth, 1992), leader trustworthiness (Mayer \& Davis, 1999), PsyCap (PsyCap Questionnaire [PCQ]; Luthans, Avolio, Norman, \& Avey, 2007), and social exchange (as relationship quality using the Multidimensional Measure of LMX [MDMLMX]; Liden \& Maslyn, 1998). Items were scored on Likert scales ranging from 1 to 7.

We also gathered a variety of individual and dyadic demographic information for leaders and followers, including gender, age, education, and work experience as well as the length of the leader-follower relationship. However, demographic characteristics were rarely significant predictors of the outcomes, and even when they were, their inclusion did not substantively change the relationships of interest. They are excluded below for parsimony and clarity.

\section{Analytical Approach}

Our analysis had three steps. First, to confirm the measurement properties of the scales, we conducted a series of psychometric analyses. These tests included an assessment of reliability (Cronbach's alpha), two traditional confirmatory factory analyses (CFAs), and two multilevel CFAs. Second, we constructed G_AL scores for each follower, as described below. Finally, we used random effects multilevel modeling to assess the simultaneous influence of $P_{-} A L$ and G_AL while also accounting for the nonindependence of group members' responses. 
We calculated the G_AL score for each respondent by averaging the P_AL scores of all of the other followers of the same leader. We used an average, rather than a literal sum, to adjust for the different number of followers per leader in our data. The G_AL score was thus calculated independently of the P_AL score; a focal follower's data had no influence on the G_AL score associated with him or her. As implied by this method of calculation, each follower had a unique G_AL score. Whereas previous studies used a constant group average to measure the groupbased effects of AL, we used an individual-level one. This operationalization reflects the theoretical model described earlier, in which the group-based effect of G_AL is a result of the additive influences from a followers' coworkers.

Using such an additive model had the attractions of being consistent with our underlying theoretical model and also allowing us to clearly distinguish between P_AL and G_AL effects on follower outcomes; in contrast, the whole-group averages used in prior studies risk confounding individual and group effects (Muthén, 1994). Our G_AL measure had the further benefit of eliminating common method bias from tests of its effect on the outcomes. Since our P_AL hypothesis (Hypothesis 1) is a replication of previous findings, the effect of G AL on outcomes (Hypothesis 2) is the most important in this analysis. It is therefore a key strength of the G_AL measure that it eliminates any influence from common method bias.

\section{Results}

Although we used well-established measures with demonstrated psychometric properties, we began by assessing the performance of the scales in our sample. All scales showed good reliability, as assessed by Cronbach's alpha (see Table 2). We also conducted four CFAs to further assess the scales' performance (see Table 3). The first CFA (Model A) was a traditional one (i.e., ignoring the nonindependence of the responses), in which all constructs were included and treated as unidimensional. However, the ALQ, PCQ, and MDM-LMX measures are all known to be multidimensional, so we conducted a second traditional CFA (Model B) in which we allowed the indicators' error terms to correlate in a fashion consistent with the a priori dimensional structure of the scales (e.g., the errors of the transparency items in the ALQ were allowed to correlate with each other but not with the errors for any other items). Both of these CFAs treated the responses as independent, when they were not, which likely had a conservative effect on estimates of fit (Bliese \& Hanges, 2004; Dyer, Hanges, \& Hall, 2005). That is, the appropriateness of the measurement model is likely to be better than suggested by the results. In our final two measurement analyses, we conducted multilevel CFAs (MCFAs) of the ALQ, following the procedure described by Muthén (1994). The first MCFA (Model C) treated the ALQ as unidimensional; the second MCFA (Model D) used correlated error terms to reflect the ALQ's multidimensional structure.

While some of the fit statistics were below common rules of thumb, others were within acceptable ranges (MacCallum, Browne, \& Sugawara, 1996). Moreover, it should be remembered that the function of fit statistics is to prevent the adoption of misspecified models (Hu \& Bentler, 1999) and that fit results should not be applied in a rote, unthinking fashion (Barrett, 2007; Chen, Curran, Bollen, Kirby, \& Paxton, 2008). In this case, there were three likely factors that could have contributed to poor fit statistics: small sample size, high cross- 
loadings caused by single-source data, and genuine model misspecification. Given that all of the measures are well-established scales for equally well-established constructs and that most of the relationships have been demonstrated previously, we are inclined to think that single-source data and small sample size were the more important issues. Since Hypothesis 1 was a replication hypothesis and our measure of G_AL eliminated all common method bias from our test of Hypothesis 2, we judged that it was appropriate to proceed with our analysis.

Table 2. Descriptive Statistics

\begin{tabular}{|c|c|c|c|c|c|c|c|c|c|}
\hline Variable & Mean & $\begin{array}{l}\text { Standard } \\
\text { Deviation }\end{array}$ & $\alpha$ & 1 & 2 & 3 & 4 & 5 & 6 \\
\hline \multicolumn{10}{|l|}{ Individual } \\
\hline 1. Authentic leadership & 5.67 & 0.72 & .91 & & & & & & \\
\hline 2. Identification with leader & 4.63 & 1.04 & .79 & .23 & & & & & \\
\hline 3. Trustworthiness: Competence & 6.12 & 0.91 & .90 & .56 & .50 & & & & \\
\hline 4. Trustworthiness: Benevolence & 5.64 & 1.08 & .93 & .60 & .45 & .77 & & & \\
\hline 5. Trustworthiness: Integrity & 5.88 & 1.00 & .85 & .61 & .44 & .73 & .74 & & \\
\hline 6. Psychological capital & 5.60 & 0.76 & .95 & .27 & .12 & .25 & .18 & .25 & \\
\hline 7. Relationship quality & 5.82 & 1.00 & .94 & .51 & .27 & .46 & .51 & .47 & .26 \\
\hline \multicolumn{10}{|l|}{ Group } \\
\hline Authentic Leadership & 5.69 & 0.42 & & & & & & & \\
\hline
\end{tabular}

Note: Correlations greater than .20 are significant $(p<.05) . N=104$ in 31 groups.

Table 3. Confirmatory Factor Analysis (CFA) Results

\begin{tabular}{|c|c|c|c|c|c|}
\hline Model & $\chi^{2}$ & $d f$ & CFI & RMSEA & SRMR \\
\hline Model A: CFA of all measures, treating them as unidimensional & 4030.54 & 2123 & .68 & .09 & .09 \\
\hline $\begin{array}{l}\text { Model B: CFA of all measures, including multidimensional structure } \\
\text { of ALQ, PCQ, and MDM-LMX }\end{array}$ & 3465.63 & 2047 & .76 & .08 & .09 \\
\hline Model C: MCFA of ALQ, treating scale unidimensional & 983.65 & 465 & .79 & .10 & .12 \\
\hline $\begin{array}{l}\text { Model D: MCFA of ALQ, including its four-part multidimensional } \\
\text { structure }\end{array}$ & 759.00 & 415 & .86 & .09 & .11 \\
\hline
\end{tabular}

Note: $N=104$ in 31 groups. CFI = comparative fit index; RMSEA = root mean square error of approximation; $\mathrm{SRMR}=$ standardized root mean square residual; ALQ = Authentic Leadership Questionnaire (Walumbwa et al., 2008); PCQ = PsyCap Questionnaire (Luthans, Avolio, Norman, \& Avey, 2007); MDM-LMX = Multidimensional Measure of Leader-Member Exchange (Liden \& Maslyn, 1998).

The results of the random effects multilevel modeling supported Hypothesis 1, indicating that P_AL was positively associated with all four of the outcomes (see Table 4). These findings replicated previous ones and suggested the comparability of our data. In contrast, there was only partial support for Hypothesis 2; G_AL was positively associated with two of the four outcomes. Specifically, Model 1 revealed that only $\mathrm{P}_{-}$AL was a significant predictor of followers' identification with their leader $(\beta=.36, p=.01)$; G_AL was not significantly related to identification $(\beta=.37, p=.19)$. In contrast, in Models 2 through 4 , both P_AL and G_AL were significant predictors of all three aspects of leader trustworthiness: competence $\left(\mathrm{P}_{-} \mathrm{AL}, \beta=\right.$ $\left..72, p<.01 ; \mathrm{G} \_\mathrm{AL}, \beta=.67, p<.01\right)$, benevolence $\left(\mathrm{P} \_\mathrm{AL}, \beta=.90, p<.01 ; \mathrm{G} \_\mathrm{AL}, \beta=.92, p<\right.$ $.01)$, and integrity $\left(\mathrm{P} \_\mathrm{AL}, \beta=.84, p<.01 ; \mathrm{G} \_\mathrm{AL}, \beta=.96, p<.01\right)$. Followers' PsyCap was significantly predicted by $\mathrm{P} \_\mathrm{AL}($ Model $5 ; \beta=.29, p<.01)$ but not $\mathrm{G}_{-} \mathrm{AL}(\beta=.20, p=.24)$. As shown in Model 6, the quality of the relationship that followers perceived with their leaders was significantly related to both $\mathrm{P}_{-} \mathrm{AL}(\beta=.69, p<.01)$ and $\mathrm{G}_{-} \mathrm{AL}(\beta=.99, p<.01)$. 
Table 4. Regression Models

\begin{tabular}{|c|c|c|c|c|c|c|c|}
\hline Predictor & $\begin{array}{c}\text { Model } 1 \\
\text { Identification } \\
\text { With Leader }\end{array}$ & $\begin{array}{c}\text { Model 2 } \\
\text { Trust: } \\
\text { Competence } \\
\end{array}$ & \begin{tabular}{|c|} 
Model 3 \\
Trust: \\
Benevolence \\
\end{tabular} & \begin{tabular}{|c|} 
Model 4 \\
Trust: Integrity
\end{tabular} & $\begin{array}{c}\text { Model 5 } \\
\begin{array}{c}\text { Psychological } \\
\text { Capital }\end{array} \\
\end{array}$ & $\begin{array}{c}\text { Model 6 } \\
\text { Relationship } \\
\text { Quality } \\
\end{array}$ & $\begin{array}{c}\text { Model } 7 \\
\text { Team } \\
\text { Performance } \\
\end{array}$ \\
\hline Intercept & 2.52 & $2.33^{*}$ & .43 & .43 & $4.45^{*}$ & .19 & -1.42 \\
\hline $\begin{array}{l}\text { Generalized authentic } \\
\text { leadership }(\mathrm{G} A L)\end{array}$ & $\begin{array}{c}0.37[-0.18 \\
0.93]\end{array}$ & $\begin{array}{c}0.67^{*}[0.31 \\
1.03]\end{array}$ & $\begin{array}{c}0.92^{*}[0.51 \\
1.33]\end{array}$ & $\begin{array}{c}0.96^{*}[0.59 \\
1.33]\end{array}$ & $\begin{array}{c}0.20[-0.14 \\
0.54]\end{array}$ & $\begin{array}{l}0.99^{*}[0.60 \\
1.39]\end{array}$ & $\begin{array}{l}0.50^{*}[0.06 \\
0.94]\end{array}$ \\
\hline $\begin{array}{l}\text { Personalized authentic } \\
\text { leadership (P_AL) }\end{array}$ & $\begin{array}{l}0.36^{*}[0.09 \\
0.64]\end{array}$ & $\begin{array}{l}0.72^{*}[0.51 \\
\quad 0.92]\end{array}$ & $\begin{array}{l}0.90^{*}[0.67 \\
1.14]\end{array}$ & $\begin{array}{c}0.84^{*}[0.63 \\
1.06]\end{array}$ & $\begin{array}{l}0.29^{*}[0.09 \\
0.49]\end{array}$ & $\begin{array}{l}0.69^{*}[0.46 \\
0.92]\end{array}$ & \\
\hline Pseudo $R^{2}$ & .09 & .34 & .34 & .36 & .08 & .16 & $R^{2}=.20$ \\
\hline $\begin{array}{l}\text { Likelihood ratio of } \\
\text { model compared to } \\
\text { null }\end{array}$ & $6.99^{*}$ & $40.23^{*}$ & $46.74^{*}$ & $48.44^{*}$ & $8.34^{*}$ & $31.10^{*}$ & $F(1,22)=5.56^{*}$ \\
\hline
\end{tabular}

Note: $95 \%$ confidence intervals in square brackets. Models 1 through $6, N=104$ in 31 groups. Model 7 was at the group level, $N=24$.

$* p<.05$.

As an additional test of the importance and predictive power of AL, we collected performance data for 24 of the 31 surveyed teams. The organization's HR department used a proprietary scoring system to evaluate each team's overall performance on a 3-point scale $(M=1.42, S D=$ $0.5)$. We used a G_AL score based on the average of all team members' $\mathrm{P} \_$AL ratings, and this value was a significant predictor of team performance (Model $7 ; \beta=.50, \bar{p}=.03$ ).

\section{Discussion}

This study's purpose was to clarify theoretical explanations of the individual and group-based influences of AL on follower responses through a comprehensive literature review and an empirical study. We found that the direct, individualized effect of AL ( $P$ AL) had positive effects on the four most important follower responses associated with AL and that there were two additional positive effects from indirect, group-based $A L\left(G_{-} A L\right)$. Below, we discuss the implications of these results, consider the limitations of our study, and suggest future research directions.

\section{Theoretical Implications}

We made three significant contributions to theory. First, we replicated previous findings by showing that a follower's perception of his or her leader's authentic behavior had a positive relationship with his or her responses to the authentic leader. Assessing the direct relationships between AL and follower outcomes was essential to test our key hypothesis about the additional effects of G_AL, but the replication also makes a valuable contribution in itself. There is a growing recognition of the importance of replication in management research (e.g., Eden, 2002) and calls for replication studies (e.g., Honig \& Bedi, 2012). Our analysis responds to these calls.

Second, we found that the perceptions of AL among a follower's coworkers provided an additional influence on that follower's responses to the leader. Demonstrating and explaining this second, generalized effect of AL was an entirely new contribution that addressed important theoretical and methodological gaps in the literature. Our third contribution is closely related, in offering a different way to conceptualize and measure the group-based effects of AL, one which 
responds to calls for coherent theory on the nature of group phenomenon that is aligned with the methods used (Chan, 2011). Below, we discuss implications of each of these contributions in turn.

We found that personalized AL had positive effects on the most important follower responses associated with AL. Specifically, a follower's own perceptions of the authentic leader predicted that follower's identification with the leader, level of PsyCap, and extent of positive social exchange with the leader. These three findings replicated and supported those of prior research. As well, we found that an individual's perception of the leader's behavior predicted how trustworthy the leader seemed to the follower. Previous studies have linked AL and trust (Erkutlu \& Chafra, 2013; Wong et al., 2010; Wong \& Giallonardo, 2013; Wong \& Cummings, 2009) and shown that leader trustworthiness and trust are related (Wong \& Cummings, 2009), but ours was the first study to directly link AL to followers' perceptions of leader trustworthiness. In sum, our individual-level findings are consistent with those of previous studies and support existing AL theory.

Where we advanced AL theory was in theorizing that followers of authentic leaders are more likely to exert social influence on their fellow followers and, in so doing, move them to emulate positive responses to the leader. That is, in addition to the direct effect of one follower's personal experience of AL, we predicted that the follower would also display outcomes associated with AL as a result of peer influence. We expected the level of AL experienced by peers to predict the outcomes of a focal follower. Consistent with this prediction, we found that coworker perceptions of the authentic leader's behavior had an additional influence on follower ratings of the leader's trustworthiness and positive social exchange. These results suggest that an authentic leader has both a personalized and a generalized influence on individual followers. By implication, individual leader-follower relationships cannot be fully understood when examined in isolation from the broader group in which those relationships exist (see also Henderson et al., 2009; Nielsen \& Daniels, 2012).

However, we did not find the expected relationship between G_AL and follower identification with the leader. We anticipated the AL experiences of a follower's coworkers would increase the follower's identification with the leader, but the data did not support our expectation. This result may reveal that a follower's identification with the leader is primarily a dyadic response, influenced most by idiosyncratic characteristics of the leader and follower (e.g., personality; Dulebohn, Bommer, Liden, Brouer, \& Ferris, 2011).

Similarly, we failed to find the expected relationship between $G_{-}$AL and the positive state of PsyCap. We thought that followers' interactions with AL-influenced coworkers would alter their PsyCap but found no evidence of such. While the relationship between G_AL and follower PsyCap has not been previously examined, prior research suggests relationships among G_AL and positive mood (Hsiung, 2012) and self-efficacy (Özkan \& Ceylan, 2012), from which one might infer a relationship with PsyCap. However, our findings underscore the importance of not equating positive mood with PsyCap. Prior research indicates that mood is subject to emotional contagion (Barsade, 2002; Dasborough, Ashkanasy, Tee, \& Tse, 2009), but PsyCap, while being more malleable than fixed states, like personality and intelligence, is a relatively stable state and less susceptible to change (Luthans et al., 2007). 
In describing $\mathrm{G}$ AL, we provided the first thorough theoretical explanation for how AL influences individual followers through group-based processes. As a part of this explanation, we argued for the appropriateness of an additive composition model. This model contrasts with prior studies, which all used a direct consensus model but did so without explaining its appropriateness. The key difference between the two models concerns the existence of a grouplevel phenomenon. In a direct consensus model, a shared, group-level phenomenon of "aggregate" or "uniformly displayed" AL is assumed to exist. In contrast, an additive model does not require the existence of a distinct group-level phenomenon; rather, the effect of the group is the additive result of individual contributions. Since the majority of previous studies showed poor evidence to support the existence of an aggregate phenomenon, and no clear theoretical explanation of such a construct has yet been offered, we propose that the use of an additive model is more appropriate.

An additive composition model also seems more consistent with AL theory, which asserts that leaders will behave differently with different followers (Yammarino et al., 2008). In other words, current theory allows - even expects - that one follower may report higher AL behavior than another follower of the same leader. Such difference is problematic for a direct consensus model but not for an additive one. As such, we argued that the authentic leader's group effect results from the additive consequences of each individual member's perception of the leader. We explained how the more authentic leader behavior a leader displays with any given follower, the more that follower will exhibit associated behavioral and attitudinal changes, and those changes will subsequently influence that follower's coworkers.

Adopting this additive model has many advantages. As noted, it is more consistent with existing theory. It is also more parsimonious, in not relying on the existence of an additional, aggregatelevel construct. Moreover, the mechanisms underlying the generalized influence of AL are grounded in well-established social influence processes. The use of an additive model allows for the calculation of completely independent scores for personalized and generalized leadership, preventing any confounding of effects. Furthermore, in not relying on agreement among followers, the additive model approach may reduce the prevalence of Type II error in the literature, as there will be no disincentive for researchers whose data fail to show appropriate levels of agreement among followers. We recommend that future studies examining the relationship between AL and follower outcomes adopt the use of an additive composition model.

In making this recommendation, we recognize that it raises intriguing questions about the notion of a "multilevel" study. We had no true group-level variable in our model, and the additive composition approach might be characterized as reductionist, in that it explains the effect of the group as an accumulation of individual-level interactions. Some might consider our G_AL measure to be an individual-level context variable, since each follower has a unique score derived from the experiences of his or her coworkers. Nonetheless, this measure still captures the nature of the group that is influencing the individual, and in that way it is a group variable; the effect would not exist in the absence of that particular work group. Our research is therefore a part of the study of multilevel leadership and offers additional issues to be considered in developing multilevel theory and methods. The theoretical and methodological treatment of leader-via-coworker effects should be included in the understanding of leadership processes. 
Moreover, while we are skeptical about the utility of direct consensus composition in the study of AL, we do not deny the potential importance of group-level phenomena. In fact, two other composition models - referent shift and group dispersion - may be very important and should be considered in future studies. Both of these models involve genuine group-level variables, and we suspect they will provide important new insights.

When using a referent shift composition model, the focus is explicitly changed to how the leader acts toward the group as a whole (Chan, 1998; Wallace et al., 2016). For example, transformational leadership researchers have developed a multilevel measure to distinguish between individual- and group-focused leadership behaviors (X. Wang \& Howell, 2010). There is as yet no comparable measure for AL, but the matter deserves investigation. One can imagine that followers would react quite differently to a leader who seemed authentic in individual interactions but not with the group as a whole or vice versa.

Likewise, a dispersion composition model may also reveal important aspects of the AL process. When using a dispersion model, the level of agreement among team members becomes the variable of interest; one contrasts high-agreement groups with low-agreement groups to assess their differences (Chan, 1998). Research on LMX has demonstrated the potential power of differing levels of agreement (e.g., Henderson et al., 2009; Tse, Ashkanasy, \& Dasborough, 2012; Wu et al., 2010). Relative to our theory in this article, one might expect that high agreement among followers would intensify the effects of G_AL on an individual follower by strengthening social influence (e.g., Meindl, 1990, 1995; Wu et al., 2010). If every coworker has high individual experiences of AL, the group influence should be more consistent and powerful than it would be if only some of the group have such experiences.

A key implication of this discussion is the need for more concrete theorizing and more complex operationalization. To date, research has tended to treat AL as a blunt instrument, assessing it in only one way and focusing entirely on immediate, individual effects. Our results suggest the need for a more refined examination of how authentic leaders influence followers. We hope that this article is just the first step in clarifying the ways in which authentic leaders influence followers.

\section{Practical Implications}

Our study demonstrates that authentic leaders can simultaneously influence followers both directly and indirectly (through a follower's coworkers). Leadership development initiatives can incorporate these findings to motivate leaders to emphasize positive interactions with all followers, even if there are some incompatibilities between them and particular followers, because interactions with one follower have implications for the responses of every other follower (also see differentiated leadership theory; Dulebohn et al., 2011).

Our article also offers a practical contribution to researchers in its extension of Gardner and colleagues' (2011) literature review. At the time of that review, the AL field was focused on developing theory rather than refining it through empirical research (Gardner et al., 2011). However, our review found that the focus has clearly shifted. Forty-six empirical studies of the 
effects of AL on followers have been added to the seven that Gardener and his colleagues identified. We provide a summary of all of these studies, categorized by outcome and level of analysis. We hope the summary assists future researchers to build on extant findings.

\section{Limitations and Future Research}

We described the social influence mechanisms by which an authentic leader may indirectly affect followers through coworkers, but testing these relationships was beyond the scope of this study. Future research could include social identification and other social influence measures to assess when one type of influence is more important than another and how the three interact. Moreover, as this line of investigation develops, it may be possible to introduce specific coworker outcomes as mediators. That is, we hope that theory advances to the point where we can identify the specific response in one follower that most fosters the social influence process to affect a peer's outcome. Current AL theory is not sufficiently developed for such specific predictions, but we hope that this study contributes toward that development.

In addition, the generalizability of our findings is uncertain. Our sample was drawn from just one organization. We studied relatively effective leaders of small groups who worked closely with their followers. While we are not aware of any reason for doubting the generalizability of our results, future research should use different and more diverse samples.

In conclusion, we found that AL influences followers both directly and indirectly, through its influence on coworkers. We provided possible explanations for these indirect effects, which had not previously been considered, and we reported evidence consistent with those explanations. It is our belief that such indirect, peer-influence processes are a better way of assessing the groupbased effects of AL. This approach is also more consistent with existing theory. Future theorizing and investigation should take account of the multiple effects of AL and strive to match methods to theory. There is ample evidence of the practical importance of AL, which underscores the need for thorough and appropriate theory about AL.

\section{Acknowledgements}

This article was accepted under the editorship of Deborah E. Rupp. We are grateful to Peter Jordan and Hannes LeRoy for their feedback on an early draft of this paper as well as to the participants at the 7th Asia Pacific Symposium of Emotions in Work Life (APSEW), where an earlier version of this paper was presented. We also thank the University of Melbourne for an early career grant that funded the collection of this data and Griffith University's Centre for Work, Organisation, and Wellbeing for supporting the editing of this paper. In addition, we thank J. Craig Wallace and our anonymous reviewers for their valuable and constructive comments.

\section{References}

Abrams, D., Hogg, M. A. 1990. Social identification, self-categorization and social influence. European Review of Social Psychology, 1: 195-228.

Alok, K. 2014. Authentic leadership and psychological ownership: Investigation of interrelations. Leadership and Organization Development Journal, 35: 266-285. 
Alok, K., Israel, D. 2012. Authentic leadership and work engagement. Indian Journal of Industrial Relations, 47: 498-510.

Avey, J. B. 2014. The left side of psychological capital: New evidence on the antecedents of PsyCap. Journal of Leadership and Organizational Studies, 21: 141-149.

Avolio, B. J., Gardner, W. L. 2005. Authentic leadership development: Getting to the root of positive forms of leadership. Leadership Quarterly, 16: 315-338.

Avolio, B. J., Gardner, W. L., Walumbwa, F. O., Luthans, F., May, D. R. 2004. Unlocking the mask: A look at the process by which authentic leaders impact follower attitudes and behaviors. Leadership Quarterly, 15: 801-823.

Avolio, B. J., Reichard, R. J. 2008. The rise of authentic followership. In Riggio, R. E., Chaleff, I., Lipman-Blumen, J. (Eds.), The art of followership: How great followers create great leaders and organizations: 325-338. San Francisco: Jossey-Bass.

Azanza, G., Moriano, J. A., Melero, F. 2013. Authentic leadership and organizational culture as drivers of employees' job satisfaction. Journal of Work and Organizational Psychology, 29: 45-50.

Bamford, M., Wong, C. A., Spence Laschinger, H. K. S. 2013. The influence of authentic leadership and areas of worklife on work engagement of registered nurses. Journal of Nursing Management, 21: 529-540.

Bandura, A. 1971. Social learning theory. New York: General Learning Press.

Barrett, P. 2007. Structural equation modelling: Adjudging model fit. Personality and Individual Differences, 42: 815-824.

Barsade, S. G. 2002. The ripple effect: Emotional contagion and its influence on group behavior. Administrative Science Quarterly, 47: 644-675.

Blau, P. M. 1964. Exchange and power in social life. Piscataway, NJ: Transaction.

Bliese, P. D., Hanges, P. J. 2004. Being both too liberal and too conservative: The perils of treating grouped data as though they were independent. Organizational Research Methods, 7: 400-417.

Borgersen, H. C., Hystad, S. W., Larsson, G., Eid, J. in press. Authentic leadership and safety climate among seafarers. Journal of Leadership and Organizational Studies.

Google Scholar | SAGE Journals

Brown, M. E., Trevino, L. K. 2006. Ethical leadership: A review and future directions. Leadership Quarterly, 17: 595-616.

Caza, A., Bagozzi, R. P., Woolley, L., Levy, L., Caza, B. B. 2010. Psychological capital and authentic leadership: Measurement, gender, and cultural extension. Asia-Pacific Journal of Business Administration, 2: 53-70. 
Caza, A., Jackson, B. 2011. Authentic leadership. In Bryman, D., Collinson, K., Grint, B., Jackson, B., Uhl-Bien, M. (Eds.), Sage handbook of leadership: 350-362. Thousand Oaks, CA: Sage.

Cerne, M., Dimovski, V., Maric, M., Penger, S., Skerlavaj, M. in press. Congruence of leader self-perceptions and follower perceptions of authentic leadership: Understanding what authentic leadership is and how it enhances employees' job satisfaction. Australian Journal of Management. doi:10.1177/0312896213503665.

Chan, D. 1998. Functional relations among constructs in the same content domain at different levels of analysis: A typology of composition models. Journal of Applied Psychology, 83: $234-246$.

Chan, D. 2011. Advances in analytical strategies. In Zedeck, S. (Ed.), APA handbook of industrial and organizational psychology: Vol. 1. Building and developing the organization: 85-113. Washington DC: American Psychological Association.

Chen, F., Curran, P. J., Bollen, K. A., Kirby, J., Paxton, P. 2008. An empirical evaluation of the use of fixed cutoff points in RMSEA test statistic in structural equation models. Sociological Methods and Research, 36: 462-494.

Cho, J., Dansereau, F. 2010. Are transformational leaders fair? A multi-level study of transformational leadership, justice perceptions, and organizational citizenship behaviors. Leadership Quarterly, 21: 409-421.

Cialdini, R. B., Goldstein, N. J. 2004. Social influence: Compliance and conformity. Annual Review of Psychology, 55: 591-621.

Cianci, A. M., Hannah, S. T., Roberts, R. P., Tsakumis, G. T. in press. The effects of authentic leadership on followers' ethical decision-making in the face of temptation: An experimental study. Leadership Quarterly. doi:10.1016/j.leaqua.2013.12.001.

Clapp-Smith, R., Vogelgesang, G. R., Avey, J. B. 2009. Authentic leadership and positive psychological capital: The mediating role of trust at the group level of analysis. Journal of Leadership and Organizational Studies, 15: 227-240.

Cole, M. S., Walter, F., Bedeian, A. G., O’Boyle, E. H. 2011. Job burnout and employee engagement: A meta-analytic examination of construct proliferation. Journal of Management, 38: 1550-1581.

Colquitt, J. A, Scott, B. A., LePine, J. A. 2007. Trust, trustworthiness, and trust propensity: A meta-analytic test of their unique relationships with risk taking and job performance. Journal of Applied Psychology, 92: 909-927.

Cottrill, K., Lopez, P. D., Hoffman, C. C. 2014. How authentic leadership and inclusion benefit organizations. Equality, Diversity and Inclusion: An International Journal, 33: 275-292.

Darvish, H., Rezaei, F. 2011. The impact of authentic leadership on job satisfaction and team commitment. Management and Marketing, 6: 421-436. 
Dasborough, M. T., Ashkanasy, N. M., Tee, E. Y. J., Tse, H. H. M. 2009. What goes around comes around: How meso-level negative emotional contagion can ultimately determine organizational attitudes toward leaders. Leadership Quarterly, 20: 571-585.

Dienesch, R. M., Liden, R. C. 1986. Leader-member exchange model of leadership: A critique and further development. Academy of Management Review, 11: 618-634.

Dulebohn, J. H., Bommer, W. H., Liden, R. C., Brouer, R. L., Ferris, G. R. 2011. A metaanalysis of antecedents and consequences of leader-member exchange: Integrating the past with an eye toward the future. Journal of Management, 38: 1715-1759.

Dyer, N. G., Hanges, P. J., Hall, R. J. 2005. Applying multilevel confirmatory factor analysis techniques to the study of leadership. Leadership Quarterly, 16: 149-167.

Eden, D. 2002. From the editiors: Replication, meta-analysis, scientific progress, and AMJ's publication policy. Academy of Management Journal, 45: 841-846.

Erdogan, B., Linden, R. C., Kraimer, M. L. 2006. Justice and leader-member exchange: The moderating role of organizational culture. Academy of Management Journal, 49: 395406.

Erkutlu, H., Chafra, J. 2013. Effects of trust and psychological contract violation on authentic leadership and organizational deviance. Management Research Review, 36: 828-848.

Gabarro, J. 1978. The development of trust, influence and expectations. In Athos, A. J., Gabarro, J. J. (Eds.), Interpersonal behavior: Communication and understanding in relationships: 290-303. Englewood Cliffs, NJ: Prentice Hall.

Gardner, W. L., Avolio, B. J., Luthans, F., May, D. R., Walumbwa, F. 2005. "Can you see the real me?" A self-based model of authentic leader and follower development. Leadership Quarterly, 16: 343-372.

Gardner, W. L., Cogliser, C. C., Davis, K. M., Dickens, M. P. 2011. Authentic leadership: A review of the literature and research agenda. Leadership Quarterly, 22: 1120-1145.

George, B., Sims, P. 2007. True north: Discover your authentic leadership (1st ed.). San Fransico: Jossey-Bass.

Giallonardo, L. M., Wong, C. A., Iwasiw, C. L. 2010. Authentic leadership of perceptors: Predictor of new graduate nurses' work engagement and job satisfaction. Journal of Nursing Management, 18: 993-1003.

Gooty, J., Gavin, M., Ashkanasy, N. M. 2009. Emotions research in OB: The challenges that lie ahead. Journal of Organizational Behavior, 30: 833-838.

Gooty, J., Serban, A., Thomas, J. S., Gavin, M. B., Yammarino, F. J. 2012. Use and misuse of levels of analysis in leadership research: An illustrative review of leader-member exchange. Leadership Quarterly, 23: 1080-1103.

Graen, G. B., Uhl-bien, M. 1995. Relationship-based approach to leadership: Development of leader-member exchange (LMX) theory of leadership over 25 years: Applying a multilevel multi-domain perspective. Leadership Quarterly, 6: 219-247. 
Guerrero, S., Lapalme, M. E., Seguin, M. in press. Board chair authentic leadership and non executives' motivation and commitment. Journal of Leadership and Organizational Studies. doi:10.1177/1548051814531825

Hannah, S. T., Avolio, B. J., Walumbwa, F. O. 2011. Relationships between authentic leadership, moral courage, and ethical and pro-social behaviors. Business Ethics Quarterly, 21: 555-578.

Henderson, D. J., Liden, R. C., Glibkowski, B. C., Chaudhry, A. 2009. LMX differentiation: A multilevel review and examination of its antecedents and outcomes. Leadership Quarterly, 20: 517-534.

Hogg, M. A. 2001. A social identity theory of leadership. Personality and Social Psychology Review, 5: 184-200.

Hogg, M. A., Terry, D. J. 2000. Social identity and self-categorization processes in organizational contexts. Academy of Management Review, 25: 121-140.

Hogg, M. A., Turner, J. C. 1985. Interpersonal attraction, social identification and psychological group formation. European Journal of Social Psychology, 15: 51-66.

Hogg, M. A., van Knippenberg, D. 2003. Social identity and leadership processes in groups. Advances in Experimental Social Psychology, 35: 1-52.

Hogg, M. A., van Knippenberg, D., David, E. R. I. 2012. The social identity theory of leadership: Theoretical origins, research findings, and conceptual developments. European Review of Social Psychology, 23: 258-304.

Honig, B., Bedi, A. 2012. The fox in the hen house: A critical examination of plagiarism among members of the Academy of Management. Academy of Management Learning and Education, 11: 101-123.

Hoy, W., Henderson, J. E. 1983. Principal authenticity, school climate, and pupil control. Alberta Journal of Educational Research, 29: 123-130.

Hsee, C. K., Hatfield, E., Carlson, J. G., Chemtob, C. 1990. The effect of power on susceptibility to emotional contagion. Cognition and Emotion, 4: 327-340.

Hsiung, H. H. 2012. Authentic leadership and employee voice behavior: A multi-level psychological process. Journal of Business Ethics, 107: 349-361.

Hu, L. T., Bentler, P. M. 1999. Cutoff criteria for fit indexes in covariance structure analysis: Conventional criteria versus new alternatives. Structural Equation Modeling, 6: 1-55.

Hystad, S. W., Bartone, P. T., Eid, J. 2014. Positive organizational behavior and safety in the offshore oil industry: Exploring the determinants of positive safety climate. Journal of Positive Psychology, 9: 42-53.

Ilies, R., Morgeson, F. P., Nahrgang, J. D. 2005. Authentic leadership and eudaemonic wellbeing: Understanding leader-follower outcomes. Leadership Quarterly, 16: 373-394.

Jensen, S. M., Luthans, F. 2006. Entrepreneurs as authentic leaders: Impact on employees' attitudes. Leadership and Organization Development Journal, 27: 646-666. 
Kreiner, G. E., Hollensbe, E. C., Sheep, M. L. 2006. Where is the "me" among the "we"? Identity work and the search for optimal balance. Academy of Management Journal, 49: 1031-1057.

Leroy, H., Anseel, F., Gardner, W. L., Sels, L. 2015. Authentic leadership, authentic followership, basic need satisfaction, and work role performance: A cross-level study. Journal of Management. 41: 1677-1697.

Leroy, H., Palanski, M. E., Simons, T. 2012. Authentic leadership and behavioral integrity as drivers of follower commitment and performance. Journal of Business Ethics, 107: 255264.

Li, F., Yu, K. F., Yang, J., Qi, Z., Fu, J. H. 2012. Authentic leadership, traditionality, and interactional justice in the Chinese context. Management and Organization Review, 7: 125.

Liden, R. C., Maslyn, J. M. 1998. Multidimensionality of leader-member exchange: An empirical assessment through scale development. Journal of Management, 24: 43-72.

Luthans, F., Avolio, B. J. 2003. Authentic leadership development. In Cameron, J. E., Quinn, R. E. (Eds.), Positive organizational scholarhip: Foundations of a new discipline: 241-261. San Francisco: Barrett-Koehler.

Luthans, F., Avolio, B. J., Norman, S. M., Avey, J. B. 2007. Positive psychological capital: Measurement and relationship with performance and satisfaction. Personnel Psychology, 60: 541-572.

MacCallum, R. C., Browne, M. W., Sugawara, H. M. 1996. Power analysis and determination of sample size for covariance structure modeling. Psychological Methods, 1: 130-149.

Mael, F., Ashforth, B. E. 1992. Alumni and their alma mater: A partial test of the reformulated model of organizational identification. Journal of Organizational Behavior, 13: 103-123.

Mayer, R. C., Davis, J. H. 1999. The effect of the performance appraisal system on trust for management: A field quasi-experiment. Journal of Applied Psychology, 84: 123-136.

Mayer, R. C., Davis, J. H., Schoorman, F. D. 1995. An integrative model of organizational trust. Academy of Management Review, 20: 709-734.

McKenna, B., Rooney, D., Boal, K. B. 2009. Wisdom principles as a meta-theoretical basis for evaluating leadership. Leadership Quarterly, 20: 177-190.

Meindl, J. R. 1990. On leadership: An alternative to the conventional wisdom. In Staw, B. M., Cummings, L. L. (Eds.), Research in organizational behavior: 159-203. Greenwich, CT: JAI Press.

Meindl, J. R. 1995. The romance of leadership as a follower-centric theory: A social constructionist approach. Leadership Quarterly, 6: 329-341.

Monzani, L., Ripoll, P., Peiró, J. M. 2014. Followers' agreeableness and extraversion and their loyalty towards authentic leadership. Psicothema, 26: 69-75. 
Müceldili, B., Turan, H., Erdil, O. 2013. The influence of authentic leadership on creativity and innovativeness. Procedia-Social and Behavioral Sciences, 99: 673-681.

Muthén, B. O. 1994. Multilevel covariance structure analysis. Sociological Methods and Research, 22: 376-398.

Neider, L. L., Schriesheim, C. A. 2011. The Authentic Leadership Inventory (ALI): Development and empirical tests. Leadership Quarterly, 22: 1146-1164.

Nielsen, K., Daniels, K. 2012. Does shared and differentiated transformational leadership predict followers' working conditions and well-being? Leadership Quarterly, 23: 383-397.

Nielsen, M. B. 2013. Bullying in work groups: The impact of leadership. Scandinavian Journal of Psychology, 54: 127-136.

Nielsen, M. B., Eid, J., Mearns, K., Larsson, G. 2013. Authentic leadership and its relationship with risk perception and safety climate. Leadership and Organization Development Journal, 34: 308-325.

Özkan, S., Ceylan, A. 2012. Multi-level analysis of authentic leadership from a Turkish consruction engineers perspective. South East European Journal of Economics and Business, 7: 101-114.

Peterson, S. J., Walumbwa, F. O., Avolio, B. J., Hannah, S. T. 2012. The relationship between authentic leadership and follower job performance: The mediating role of follower positivity in extreme contexts. Leadership Quarterly, 23: 502-516.

Peus, C., Wesche, J. S., Streicher, B., Braun, S., Frey, D. 2012. Authentic leadership: An empirical test of its antecedents, consequences, and mediating mechanisms. Journal of Business Ethics, 107: 331-348.

Qian, J., Lin, X., Chen, G. Z.-X. 2012. Authentic leadership and feedback-seeking behaviour: An examination of the cultural context of mediating processes in China. Journal of Management and Organization, 18: 286-299.

Randolph-Seng, B., Gardner, W. L. 2012. Validating measures of leader authenticity: Relationships between implicit/explicit self-esteem, situational cues, and leader authenticity. Journal of Leadership and Organizational Studies, 20: 214-231.

Read, E., Spence Laschinger, H. K. S. 2013. Correlates of new graduate nurses' experiences of workplace mistreatment. Journal of Nursing Administration, 43: 221-228.

Rego, A., Reis Júnior, D., Pina e Cunha, M. in press. Authentic leaders promoting store performance: The mediating roles of virtuousness and potency. Journal of Business Ethics. doi:10.1007/s10551-014-2125-8

Rego, A., Sousa, F., Marques, C., Pina e Cunha, M. 2012. Authentic leadership promoting employees' psychological capital and creativity. Journal of Business Research, 65: 429437. 
Rego, A., Sousa, F., Marques, C., Pina e Cunha, M. 2014. Hope and positive affect mediating the authentic leadership and creativity relationship. Journal of Business Research, 67: 200210.

Rego, A., Vitória, A., Magalhães, A., Ribeiro, N., Pina e Cunha, M. 2013. Are authentic leaders associated with more virtuous, committed and potent teams? Leadership Quarterly, 24: 61-79.

Shapira-Lishchinsky, O., Tsemach, S. in press. Psychological empowerment as a mediator between teachers' perceptions of authentic leadership and their withdrawal and citizenship behaviors. Educational Administration Quarterly. doi:10.1177/0013161X13513898

Sherony, K. M., Green, S. G. 2002. Coworker exchange: Relationships between coworkers, leader-member exchange, and work attitudes. Journal of Applied Psychology, 87: 542548.

Sluss, D. M., Ashforth, B. E. 2007. Relational identity and identification: Defining ourselves through work relationships. Academy of Management Review, 32: 9-32.

Song, B., Seomun, G. 2014. The influential factors related to organizational citizenship behavior of nurses: With focus on authentic leadership and organizational justice. Journal of Korean Academy of Nursing Administration, 20: 237-246.

Spence Laschinger, H. K. S. 2012. Job and career satisfaction and turnover intentions of newly graduated nurses. Journal of Nursing Management, 20: 472-484.

Spence Laschinger, H. K. S., Fida, R. in press-a. New nurses burnout and workplace wellbeing: The influence of authentic leadership and psychological capital. Burnout Research. doi:10.1016/j.burn.2014.03.002

Spence Laschinger, H. K. S., Fida, R. in press-b. A time-lagged analysis of the effect of authentic leadership on workplace bullying, burnout, and occupational turnover intentions. European Journal of Work and Organizational Psychology. doi:10.1080/1359432X.2013.804646

Spence Laschinger, H. K. S., Smith, L. M. 2013. The influence of authentic leadership and empowerment on new-graduate nurses' perceptions of interprofessional collaboration. Journal of Nursing Administration, 43: 24-29.

Spence Laschinger, H. K. S., Wong, C. A., Grau, A. L. 2012. The influence of authentic leadership on newly graduated nurses' experiences of workplace bullying, burnout and retention outcomes: A cross-sectional study. International Journal of Nursing Studies, 49: 1266-1276.

Staw, B. M., Sutton, R. I., Pelled, L. H. 1994. Employee positive emotion and favorable outcomes at the workplace. Organization Science, 5: 51-71.

Sy, T., Côté, S., Saavedra, R. 2005. The contagious leader: Impact of the leader's mood on the mood of group members, group affective tone, and group processes. Journal of Applied Psychology, 90: 295-305. 
Tajfel, H. 1982. Social psychology of intergroup relations. Annual Review of Psychology, 33: 139.

Tse, H. H. M., Ashkanasy, N. M., Dasborough, M. T. 2012. Relative leader-member exchange, negative affectivity and social identification: A moderated-mediation examination. Leadership Quarterly, 23: 354-366.

Turner, J. C. 1991. Social influence. Belmont, CA: Thomson Brooks/Cole.

van Knippenberg, D. 2011. Embodying who we are: Leader group prototypicality and leadership effectiveness. Leadership Quarterly, 22: 1078-1091.

van Knippenberg, D., Wilke, H. 1992. Prototypicality of arguments and conformity to ingroup norms. European Journal of Social Psychology, 22: 141-155.

Van Mierlo, H., Vermunt, J. K., Rutte, C. G. 2009. Composing group-level constructs from individual-level survey data. Organizational Research Methods, 12: 368-392.

Wallace, J. C., Edwards, B. D., Paul, J., Burke, M., Christian, M., Eissa, G. 2016. Change the referent? A meta-analytic investigation of direct and referent-shift consensus models for organizational climate. Journal of Management. 42: 838-861.

Walumbwa, F. O., Avolio, B. J., Gardner, W. L., Wernsing, T. S., Peterson, S. J. 2008. Authentic leadership: Development and validation of a theory-based measure. Journal of Management, 34: 89-126.

Walumbwa, F. O., Wang, P., Wang, H., Schaubroeck, J., Avolio, B. J. 2010. Psychological processes linking authentic leadership to follower behaviors. Leadership Quarterly, 21: 901-914.

Google Scholar | Crossref | ISI

Wang, H. U. I., Sui, Y., Luthans, F., Wang, D., Wu, Y. 2014. Impact of authentic leadership on performance: Role of followers' positive psychological capital and relational processes. Journal of Organizational Behavior, 35: 5-21.

Wang, X. H., Howell, J. M. 2010. Exploring the dual-level effects of transformational leadership on followers. Journal of Applied Psychology, 95: 1134-1144.

Wang, X. H., Howell, J. M. 2012. A multilevel study of transformational leadership, identification, and follower outcomes. Leadership Quarterly, 23: 775-790.

Wayne, S. J., Shore, L. M., Bommer, W. H., Tetrick, L. E. 2002. The role of fair treatment and rewards in perceptions of organizational support and leader-member exchange. Journal of Applied Psychology, 87: 590-598.

Williams, E. A., Pillai, R., Deptula, B., Lowe, K. B. 2012. The effects of crisis, cynicism about change, and value congruence on perceptions of authentic leadership and attributed charisma in the 2008 presidential election. Leadership Quarterly, 23: 324-341.

Wong, C. A., Cummings, G. G. 2009. The influence of authentic leadership behaviors on trust and work outcomes of health care staff. Journal of Leadership Studies, 3: 6-23. 
Wong, C. A., Giallonardo, L. M. 2013. Authentic leadership and nurse-assessed adverse patient outcomes. Journal of Nursing Management, 21: 740-752.

Wong, C. A., Spence Laschinger, H. K. S. 2013. Authentic leadership, performance, and job satisfaction: The mediating role of empowerment. Journal of Advanced Nursing, 69: 947959.

Wong, C. A., Spence Laschinger, H. K. S., Cummings, G. G. 2010. Authentic leadership and nurses' voice behaviour and perceptions of care quality. Journal of Nursing Management, 18: 889-900.

Woolley, L., Caza, A., Levy, L. 2011. Authentic leadership and follower development: Psychological capital, positive work climate, and gender. Journal of Leadership and Organizational Studies, 18: 438-448.

Wu, J. B., Tsui, A. S., Kinicki, A. J. 2010. Consequences of differentiated leadership in groups. Academy of Management Journal, 53: 90-106.

Yagil, D., Medler-Liraz, H. 2014. Feel free, be yourself: Authentic leadership, emotional expression, and employee authenticity. Journal of Leadership and Organizational Studies, 21: 59-70.

Yammarino, F. J., Dionne, S. D., Schriesheim, C. A., Dansereau, F. 2008. Authentic leadership and positive organizational behavior: A meso, multi-level perspective. Leadership Quarterly, 19: 693-707.

Zhang, Z., Wang, M., Shi, J. 2012. Leader-follower congruence in proactive personality and work outcomes: The mediating role of leader-member exchange. Academy of Management Journal, 55: 111-130. 